\title{
First record of Prebaetodes meridinensis Chacón, Pescador \& Segnini, 2010 (Ephemeroptera, Baetidae) from Colombia
}

\author{
Luis G. Salinas J. ${ }^{1}$, Paola A. Villegas A. ${ }^{1}$, Frederico Falcão Salles ${ }^{2}$, César Román-Valencia ${ }^{1}$ \\ 1 Universidad del Quindío, Laboratorio de Ictiología, Grupo de Investigación "Diversidad Faunística", P.O. Box.2639, Armenia, Quindío, \\ Colombia. 2 Museu Regional de Entomologia, Departamento de Entomologia, Universidade Federal de Viçosa, Avenida P. H. Rolfs, s/n - Campus \\ Universitário, Viçosa, 36570-900, Minas Gerais, Brazil. \\ Corresponding author: Luis G. Salinas J, lgsalinas@uniquindio.edu.co
}

\begin{abstract}
We present the first record in Colombia of Prebaetodes meridinensis Chacón, Pescador \& Segnini, 2010 based on nymphs collected in Andean region. This species was previously reported from Venezuela.
\end{abstract}

Key words

Andean region, Baetodes complex, South America, taxonomy.

Academic editor: Rodolfo Mariano | Received 29 August 2018 | Accepted 28 November 2018 | Published 19 April 2019

Citation: Salinas J. LG, Villegas A. PA, Salles FF, Román-Valencia C (2019) First record of Prebaetodes meridinensis Chacón, Pescador \& Segnini, 2010 (Ephemeroptera, Baetidae) from Colombia. Check List 15 (2): 323-325. https://doi.org/10.15560/15.2.323

\section{Introduction}

Prebaetodes Lugo-Ortiz \& McCafferty, 1996 is a South American genus of Baetidae (Ephemeroptera) erected by Lugo-Ortiz and McCafferty (1996) based on nymphal stages of $P$. sitesi Lugo-Ortiz \& McCafferty, 1996. The imaginal stage of Prebaetodes was later described by Chacón et al. (2010) based on a new species from Venezuela. Two species are currently recognized within the genus: P. sitesi occurring in Colombia, Ecuador, and Venezuela (Domínguez et al. 2006), and P. meridinensis Chacón, Pescador \& Segnini, 2010 restricted to Venezuela (Chacón et al. 2010). In Colombia, $P$. sitesi is widely distributed in the Andean region (i.e., Antioquia, Caldas, Cauca, Cundinamarca, Quindío, Nariño, Magdalena, Risaralda, and Valle del Cauca departments; Lugo-Ortiz and McCafferty 1996, Dias et al. 2009). Here, we report for the first time the presence of $P$. meridinensis in Colombia.

\section{Methods}

Nymphs of $P$. meridinensis were collected using an aquatic entomological net and subsequently fixed in 96\% ethanol. Specimen dissections were mounted on slides using Euparal as the mounting medium and further observed under magnification. Photographs were taken by using a stereoscopic Zeiss Stemi 2000c with an Axio Cam ERc 5s camera, and further edited with Zen 2 lite, and Photoshop CS5. Individuals were identified using original descriptions of $P$. meridinensis (Chacón et al. 2010).

Examined material is deposited in the invertebrate collection at Universidad del Quindío (MIUQ) in Armenia, Colombia and in the Entomological museum of the Universidad del Valle (MUSENUV) in Cali, Colombia. 

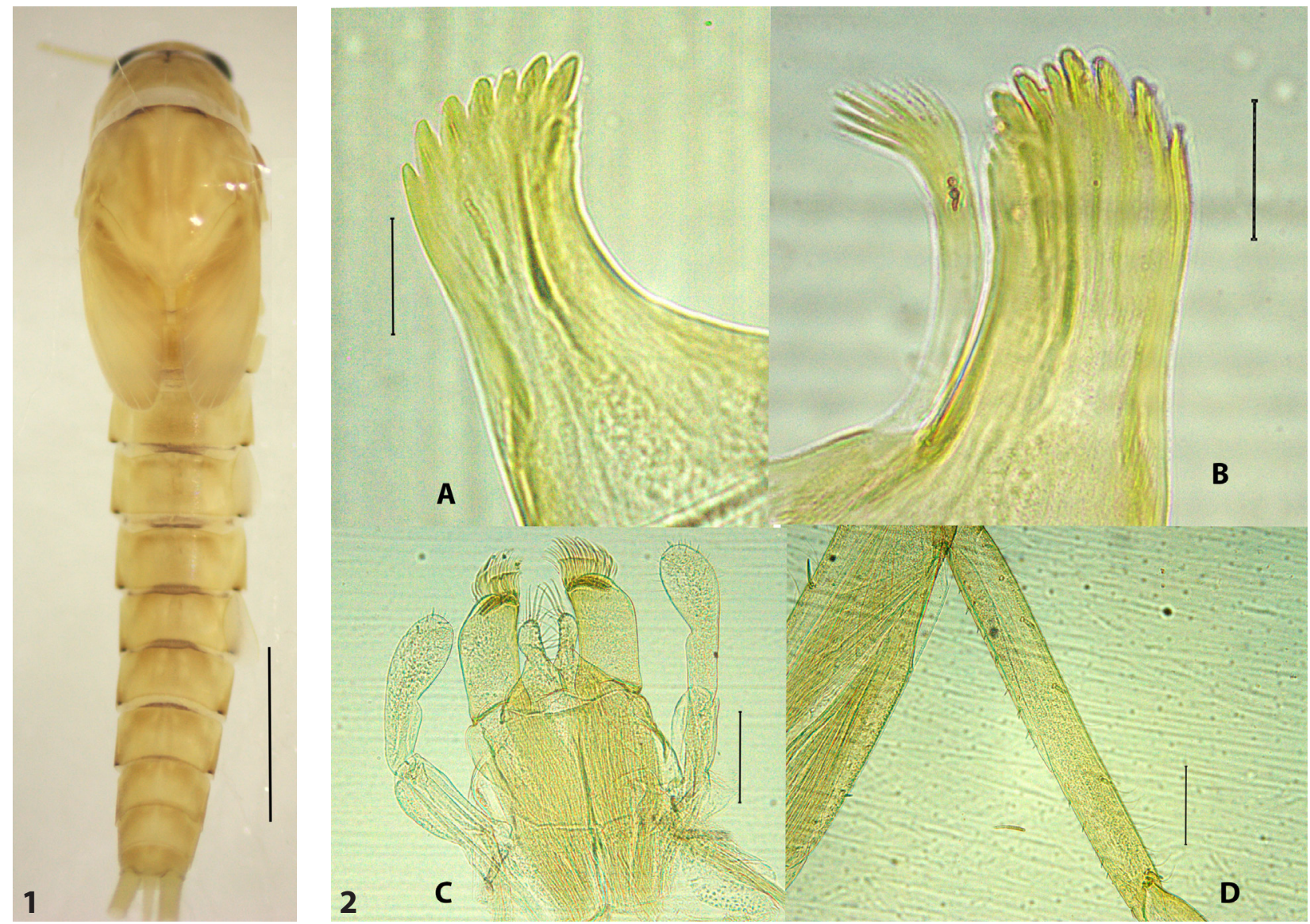

Figures 1, 2. Prebaetodes meridinensis, nymph. 1. Dorsal habitus (scale bar $=0.5 \mathrm{~mm}$ ). 2. Diagnostic characters. A. Incisors of right mandible (scale bar $=20 \mu \mathrm{m})$. B. Incisors of left mandible (scale bar $=20 \mu \mathrm{m})$. C. Labium (scale bar $=20 \mu \mathrm{m})$. D. Tibia $(\mathrm{scale}$ bar $=200 \mu \mathrm{m})$.

\section{Results}

\section{Prebaetodes meridinensis Chacón, Pescador \& Segnini, 2010}

Figure 1

Material examined. Colombia. Boyacá: Tunja $\left(05^{\circ} 38^{\prime}\right.$ 09.6"N, 073⒉ $21^{\prime} 56.21^{\prime \prime} \mathrm{W}, 3056 \mathrm{~m}$ elev.), 07/iv/2010 (MIUQ 305, 5 spec.). Caldas: Manizales; Quebrada Romerales $\left(05^{\circ} 06^{\prime} 6.7^{\prime \prime} \mathrm{N}, 075^{\circ} 23^{\prime} 5.8^{\prime \prime} \mathrm{W}, 2810 \mathrm{~m}\right.$ elev. $)$, coll. L.G. Dias, 02/vi/2011 (MIUQ 3061 spec.). Nariño: Pasto: Quebrada Purgatorio $\left(01^{\circ} 12^{\prime} 49.54^{\prime \prime} \mathrm{N}, 077^{\circ} 12^{\prime} 58.01^{\prime \prime} \mathrm{W}\right.$, 2795 m elev.), coll. L.G. Dias, 03/xi/2008 (MIUQ 307, 2 spec.); Pasto: La Cruz $\left(01^{\circ} 09^{\prime} 27.70^{\prime \prime} \mathrm{N}, 077^{\circ} 17^{\prime} 07.58^{\prime \prime} \mathrm{W}\right.$, 2800 m elev.), coll. L.G. Dias, 02/v/2008 (MIUQ 308, 2 spec.); Pasto: Mojondinoy: quebrada Santa Marta $\left(01^{\circ} 12^{\prime} 34.29^{\prime \prime} \mathrm{N}, 077^{\circ} 15^{\prime} 21.21^{\prime \prime} \mathrm{W}, 2617 \mathrm{~m}\right.$ elev.), coll. L.G. Dias, 07/vii/2008 (MIUQ 309, 1 spec.); San José $\left(01^{\circ} 28^{\prime} 20.26^{\prime \prime} \mathrm{N}, 077^{\circ} 04^{\prime} 05.35^{\prime \prime} \mathrm{W}, 2194 \mathrm{~m}\right.$ elev.), coll. L.G. Dias, 09/vi/2008 (MIUQ 310, 2 spec.); San Pablo $\left(01^{\circ} 41^{\prime} 37.36^{\prime \prime} \mathrm{N}, 077^{\circ} 00^{\prime} 59.01^{\prime \prime} \mathrm{W}, 2223 \mathrm{~m}\right.$ elev.), coll. L.G. Dias, 03/x/2008 (MIUQ 311, 3 spec.). Quindio: Calarca: Quebrada la Sonadora $\left(04^{\circ} 26^{\prime} 37.2^{\prime \prime} \mathrm{N}, 077^{\circ} 00^{\prime}\right.$ 59.01"W, $2800 \mathrm{~m}$ elev.), cols. P. Villegas, J. González, 05/xii/2010 (MIUQ 045, 6 spec.). Santander: Curití $\left(06^{\circ} 37^{\prime} 09.44^{\prime \prime} \mathrm{N}, 073^{\circ} 03^{\prime} 59.76^{\prime \prime} \mathrm{W}, 1674 \mathrm{~m}\right.$ elev.), coll. M.Z. Zuñiga, 09/v/2009 (MUSENUV 29216, 2 spec.)
Identification. Prebaetodes meridinensis can be distinguished from $P$. sitesi by the following characters: dorsolateral row of long setae on scapes: absent in $P$. meridinensis, present in $P$. sitesi (Chacón et al. 2010: fig. 12); P. meridinensis has right mandible with 8 denticles on mandibular incisors (Fig. 2A) and left mandible with 10 denticles on mandibular incisors (Fig. 2B), P. sitesi has 7 and 9 denticles on right and left incisors; shape of the ventrodistal rows of long setae on paraglossa: the 2 most proximal rows have pectinate setae and the distal row has plumose setae (Chacon et al. 2010: fig. 18a, b), in $P$ sitesi, all of these setae are pectinate; segment II of labial palp straight medially in P. meridinensis (Fig. 2C), concave medially in $P$. sitesi; shape of tibiae: straight in P. meridinensis, (Fig. 2D), somewhat twisted in P. sitesi; dorsal edge of tibia with row of 5-8 spine-like setae in $P$. meridinensis (Fig. 2D), 9-10 in P. sitesi. (The identification was based on Chacón et al. 2010.)

Distribution. Venezuela (Mérida), Colombia (Boyacá, Caldas, Nariño, Quindío, and Santander) (Fig. 3).

\section{Discussion}

Prebaetodes meridinensis is occurs in the state of Merida, in the Venezuelan Andes. In Colombia, this species is recorded from the Andean departments of Boyacá, Caldas, Nariño, Quindío, and Santander. Specimens of 


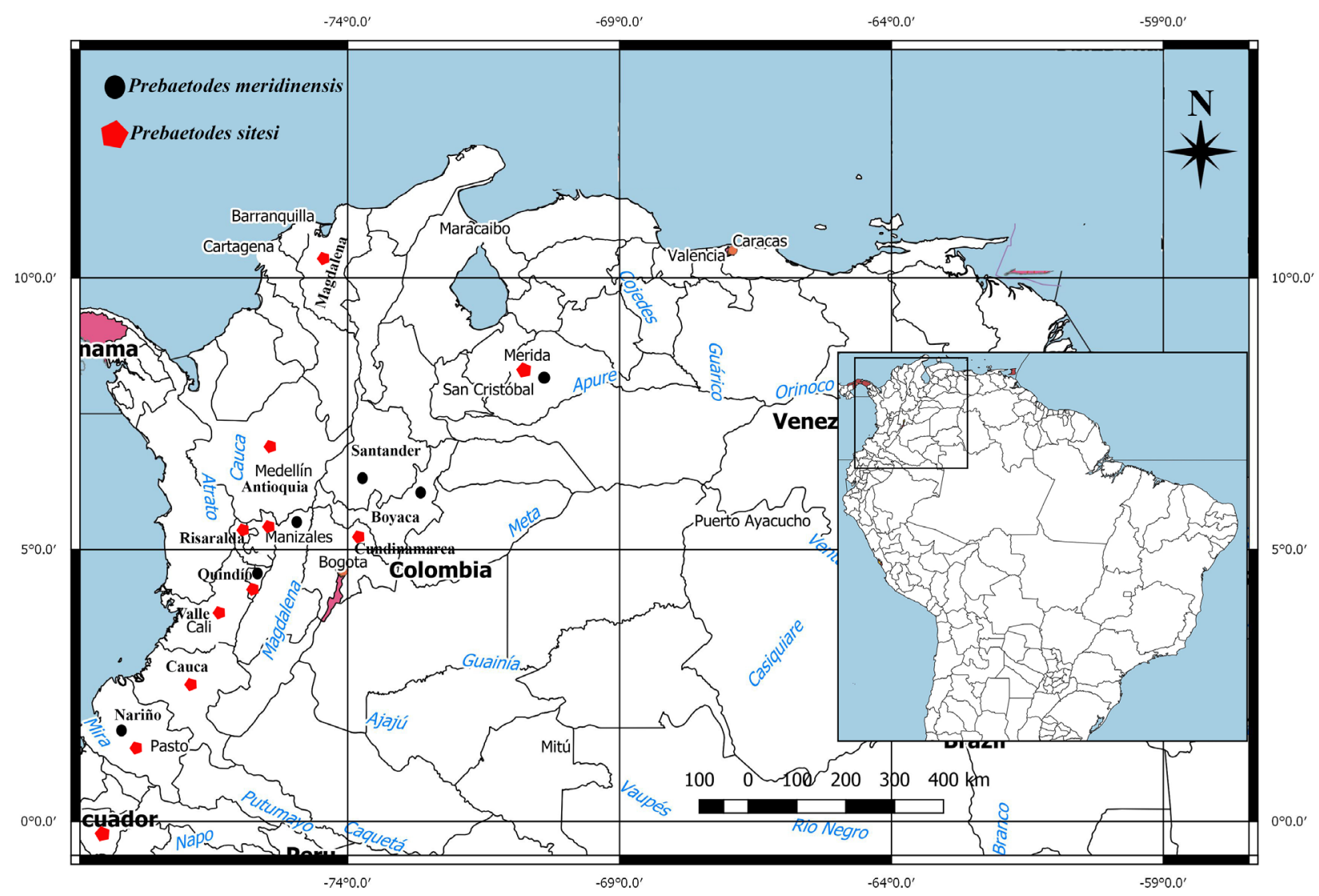

Figure 3. Geographic distribution in South America of Prebaetodes meridinensis and P. sitesi.

P. meridinensis in Venezuela and Colombia are found in freshwater habitats at high elevations. In Venezuela, this species has been collected from streams located at altitudes between 870 and $2315 \mathrm{~m}$ (Chacón et al. 2010). Our new records suggest that this species occurs at higher altitudes, from 1674 to $3056 \mathrm{~m}$. Thus, we suggest that $P$. meridinensis is a species of the highlands and appears to be mainly restricted to localities in the Andes.

\section{Acknowledgements}

We thank to Ramiro Garcia Arias of the Faculty of Basic Sciences at Universidad del Quindio, Armenia, Colombia for the financial support for 3 research visits during the second semester of 2015, the second semester of 2016 and in June 2018 to one of us (LGSJ). COLCIENCIAS and Vicerrectoría de Investigaciones de la Universidad del Quindío,Armenia, Colombia (Programa Jóvenes Investigadores and Proyect 824) to 2 of us (CRV and PAVA). We also thank Lucimar Gomes Días (Universidad de Caldas, Manizales, Colombia) for reviewing the material and Cristian Román-Palacios for critically reading an initial version of this paper.

\section{Authors' Contributions}

LGSJ and PAVA collected the data; LGSJ, PAVA and FFS identified the material; LGSJ, PAVA, FFS and CRV wrote the text.

\section{References}

Chacón MM, Pescador ML, Segnini S (2010) The adult and redefinition of the genus Prebaetodes Lugo-Ortiz \& McCafferty (Ephemeroptera: Baetidae), with description of a new species from Venezuela. Aquatic Insects, 32: 143-157. https://doi.org/10.1080/01650424.2 010.482940

Dias LG, Zuñiga MC, Bacca T (2009). Estado actual del conocimiento del orden Ephemeroptera en Colombia. In: Congreso Sociedad Colombiana de Entomología, 36 ${ }^{\circ}$. Memorias. Sociedad Colombiana de Entomología, Medellin, Colombia, 236-253.

Domínguez E, Molineri C, Pescador ML, Hubbard MD, Nieto C (2006) Diversidad Acuática en América Latina. Vol. 2, Ephemeroptera de América del Sur. Pensoft, Sofia/Moscow, 646 pp.

Lugo-Ortiz CR, McCafferty WP (1996) Phylogeny and classification of the Baetodes complex (Ephemeroptera: Baetidae), with description of a new genus. Journal of the North American Benthological Society $15: 367-380$. 